\title{
Rhizobacteria-Induced Priming in Arabidopsis Is Dependent on Ethylene, Jasmonic Acid, and NPR1
}

\author{
II-Pyung Ahn, ${ }^{1}$ Sang-Woo Lee, ${ }^{2}$ and Seok-Cheol Suh ${ }^{1}$ \\ ${ }^{1}$ National Institute of Agricultural Biotechnology, Rural Development Administration, Suwon, 441-100, Korea; ${ }^{2}$ Gyeonggi \\ Province Agricultural Research and Extension Services, Hwaseong, 445-972, Korea
}

Submitted 12 May 2006. Accepted 29 January 2007.

A nonpathogenic rhizobacterium, Pseudomonas putida LSW17S, elicited systemic protection against Fusarium wilt and pith necrosis caused by Fusarium oxysporum f. sp. lycopersici and $P$. corrugata in tomato (Lycopersicon esculentum L.). LSW17S also confers disease resistance against $P$. syringae pv. tomato DC3000 (DC3000) on Arabidopsis ecotype Col-0. To investigate mechanisms underlying disease protection, expression patterns of defense-related genes PR1, PR2, PR5, and PDF1.2 and cellular defense responses such as hydrogen peroxide accumulation and callose deposition were investigated. LSW17S treatment exhibited the typical phenomena of priming. Strong and faster transcription of defense-related genes was induced and hydrogen peroxide or callose were accumulated in Arabidopsis treated with LSW17S and infected with DC3000. In contrast, individual actions of LSW17S and DC3000 did not elicit rapid molecular and cellular defense responses. Priming by LSW17S was translocated systemically and retained for more than 10 days. Treatment with LSW17S reduced pathogen proliferation in Arabidopsis ecotype Col-0 expressing bacterial NahG; however, npr1, etr1, and jar1 mutations impaired inhibition of pathogen growth. Cellular and molecular priming responses support these results. In sum, LSW17S primes Arabidopsis for NPR1-, ethylene-, and jasmonic acid-dependent disease resistance, and efficient molecular and cellular defense responses.

Additional keyword: induced systemic resistance.

Plants have well-organized defense systems that decipher pathogen signals and induce appropriate defenses. Timely recognition of pathogen attack and prompt expression of pertinent defense responses are the key differences between compatible (susceptible) and incompatible (resistant) interactions (Bennett et al. 2005; Lu et al. 2004; McDowell and Dangl 2000; Umemura et al. 2003; Yang et al. 1997). The resistance $(R)$ gene product of a plant acts as a receptor for the corresponding pathogen's avirulence $(A v r)$ gene product and their interaction sequentially triggers defense-related responses. Subsequent defense responses have many features in common with those of systemic resistance induced by certain rhizobacteria.

Rhizobacteria protect susceptible plants from multiplepathogen infection. Moreover, they promote plant growth and provide other benefits for environmental safety. There is ample research elucidating bacterial factors and plant mechanisms

Corresponding author: I.-P. Ahn; Telephone: 82-31-299-1719; Fax: 82-31299-1692; E-mail: jinhyung@rda.go.kr responsible for the broad spectrum of disease protection. A series of elegant research projects has been performed to dissect the signaling pathways and plant genes essential for induced systemic resistance (ISR), triggered by a strain of Pseudomonas fluorescens, using an Arabidopsis-based pathosystem (Pieterse et al. 1996, 1998, 2000; Ton et al. 2001; van Wees et al. 2000; Verhagen et al. 2004). Rhizobacteria enhance disease resistance through activation of specific defense mechanisms; for example, cell wall reinforcements (Benhamou et al. 1996), accumulation of defense-related materials and enzymes (Benhamou et al. 1998; Chen et al. 2000), secondary metabolite production (Ongena et al. 2000), and impediment of infection processes of pathogens such as inhibition of sporangial and zoospore germination (Yan et al. 2002). Lipopolysaccharides, siderophores, or salicylic acid from rhizobacteria also are indispensable for successful disease protection (Buysens et al. 1996; De Meyer et al. 1999; Ramamoorthy et al. 2001).

One of the most interesting results described in previous literature is the relationship between expression of defense-related responses and disease protection by ISR. Elevation of defenserelated gene transcriptions has been assumed as molecular evidence of whether or not resistance is induced (Friedrich et al. 1996; Gaffney et al. 1993; Gorlach et al. 1996; Kim et al. 2004; Park and Kloepper 2000). However, some agents do not trigger cellular and molecular defense responses per se even though they confer obvious disease resistance on the susceptible plants (Conrath et al. 2001; Graham and Graham 1994; Pieterse et al. 2001; Ryu et al. 2003; Ton et al. 2005). Discrepancy between disease protection and transcription of defense-related genes has been an interesting theme in ISR. Subsequent pathogen challenge on the plants pretreated with the above agents entailed augmented defense-related responses such as fortified defense-related gene expression, accumulation of active oxygen species (AOS), callose deposition, and papillae formation singly or in combination. This facet brings up the rapid and efficient activation of defense systems in immunized animals and humans infected by a pathogen (Cho et al. 2002; Ludewig et al. 1998). The enhanced capacity to express pertinent defense mechanisms is termed "elicitation competency" (Graham and Graham 1994) or "priming" (Conrath et al. 2001, 2002). Agents inducing priming do not activate the plant's defense responses, but rather enhance the plant's ability to suppress future pathogen attacks (Conrath et al. 2002; Jakab et al. 2001, 2005; Pozo et al. 2004; Ton et al. 2005; Zimmerli et al. 2000). In this respect, primed plants share many characteristics with resistant plants harboring $R$ genes. There is evidence that priming is not an uncommon phenomenon in induced resistance. For example, low doses of plant defense activators such as benzo(1,2,3)-thiadiazole-7-carbothioic acid S-methyl ester (BTH), $\beta$-aminobutyric acid (BABA), 2,6-dichloroisonicotinic acid 
(DCINA), salicylic acid, and methyl jasmonate are capable of priming a susceptible host (Conrath et al. 2002; Faize et al. 2004; Si-Ammour et al. 2003). Priming is one of the most efficient types of induced resistance because the metabolic investment of the plant for the constitutive activation of the defense system is reduced or prevented. Molecular research on priming by rhizobacteria has focused on identifying plant genes through analyses of gene expression before and after pathogen challenge in the rhizobacteria-treated plants (Verhagen et al. 2004), screening of gene-trap lines, and map-based cloning.

Virulent pathogens induce rapid cellular defense responses such as production of AOS, callose and phenolic compound deposition, and augmented expression of defense-related genes in plants treated with biological control agents or plant defense activators (Faize et al. 2004; Jeun et al. 2004; Pare et al. 2005; D.-S. Park et al. 2002; K. Park et al. 2000; Ryu et al. 2000; Yedidia et al. 1999). In addition to arresting pathogen proliferation in planta, AOS is involved in cell wall reinforcement (Olivain et al. 2003) and acts as signaling molecules mediating systemic resistance (Alvarez et al. 1998; Bolwell et al. 1995, 1998; Chamnongpol et al. 1998; Tenhaken et al. 1995; Wojtaszek 1997). Callose is a fluorescent $\beta$-1,3-glucan complex and its rapid deposition is an indicator of defense-related responses (Devadas et al. 2002; Flors et al. 2005; Ton and Mauch-Mani 2004). In the absence of elicitors or subsequent stress, methyl jasmonate, salicylic acid, or DCINA alone did not induce AOS elevation or callose accumulation in the cul- tured parsley cells or cucumber hypocotyls (Conrath et al. 2001; Kauss et al. 1999).

In previous research, we showed the effect of $P$. putida LSW17S as a biocontrol agent inhibiting multiple fungal and bacterial diseases in Solanaceous crops (Lee et al. 2005). Treatment with LSW17S protected tomato (Lycopersicon esculentum L.) against Fusarium wilt and its culture filtrate inhibited conidial germination of plant pathogens (Lee 2004). Although this in vitro effect should be one of the mechanisms of disease resistance, impairment of conidial germination alone is insufficient to explain the broad spectrum of systemic resistance conferred by this specific rhizobacterium.

The aims of this study were to characterize the defenserelated cellular and molecular responses of plants treated with strain LSW17S, and to investigate the relationship between resistance and priming. To accomplish these goals, the effects of pathogen inoculation on the expression of defense-related genes and induction of cellular defense responses such as AOS accumulation and callose deposition were analyzed in Arabidopsis ecotype Col-0 and four of its defense signaling mutants.

\section{RESULTS}

\section{P. putida LSW17S protects Arabidopsis against bacterial infection.}

The bioprotection capacity of $P$. putida LSW17S was assessed in Arabidopsis thaliana ecotype Col-0, which is susceptible to $P$.
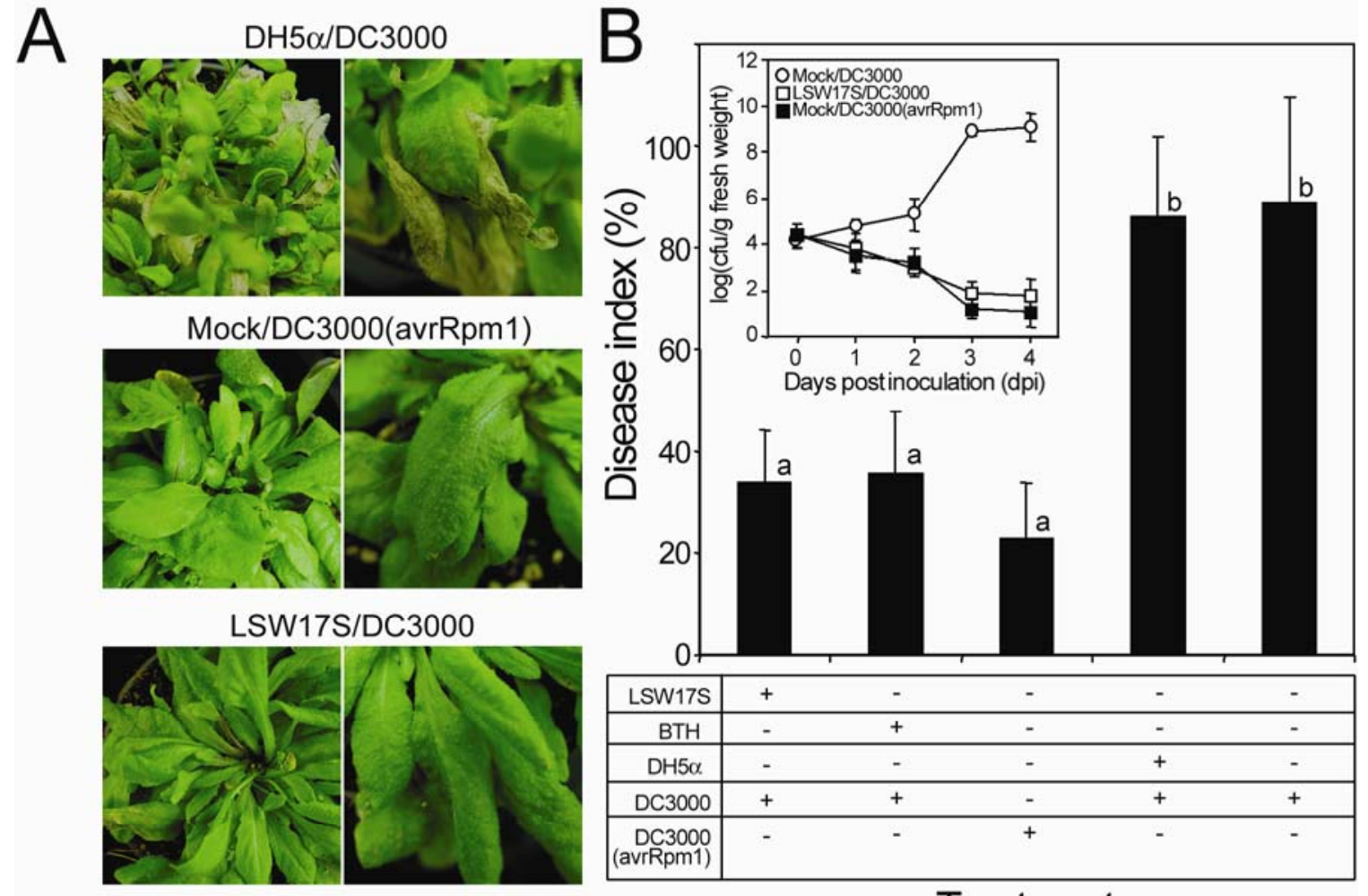

Treatments

Fig. 1. Responses of Arabidopsis to Pseudomonas syringae pv. tomato DC3000 (DC3000) infection after P. putida LSW17S treatment. A, Necrotic lesions normally present on Arabidopsis ecotype Col-0 due to DC3000 are suppressed in LSW17S-treated leaves. Col-0 plants treated with Escherichia coli DH5a also were inoculated 5 days later with DC3000 or DC3000 expressing avrRpm1 (DC3000[avrRpm1]) at $10^{8} \mathrm{CFU} / \mathrm{ml}$ in $0.85 \% \mathrm{NaCl}$, Tween 20 at $250 \mu \mathrm{g} / \mathrm{ml}$ as control. Representative plant from each treatment was photographed 5 days postinoculation (dpi). B, Quantification of systemic resistance against DC3000 infection in Arabidopsis. Plants were treated with LSW17S (+), $1.2 \mathrm{mM}$ benzo-(1,2,3)-thiadiazole-7-carbothioic acid $S$-methyl ester (BTH; +), or DH5 $\alpha(+)$ in $0.85 \% \mathrm{NaCl}$ or $0.85 \% \mathrm{NaCl}$ only (-). Leaves were sprayed with $0.85 \% \mathrm{NaCl}$ and Tween 20 at $250 \mu \mathrm{g} / \mathrm{ml}$ (mock, - ) or inoculated with DC3000(avrRpm1) (+) or DC 3000 (+) 5 days later. Data are means (disease index of the percentage of symptomatic leaves relative to control plants [100\%]) with standard errors from 25 plants. Ratings were performed 5 dpi. Different letters indicate statistically significant differences among treatments (Duncan's multiple range tests; $P<0.05)$. Inset: time course of bacterial growth in the leaves treated with mock or LSW17S and inoculated with DC3000 or DC3000(avrRpm1). Data points are means (CFU per $0.1 \mathrm{~g}$ ) with standard errors from 25 randomly selected leaves. All experiments were done more than three times and similar results were obtained. 
syringae pv. tomato DC3000 (DC3000). Avirulent DC 3000 expressing avrRpm1 (DC3000[avrRpm1]) also was inoculated onto Col-0 as a resistant control. Plants pretreated with either ISR-activating bacterial strain LSW17S or non-ISR-activating strain Escherichia coli DH5 $\alpha$ and challenged with DC3000 5 days later are shown in Figure 1A. Yellowing and water-soaking symptoms were observed on the leaves of mock- or DH5 $\alpha$ treated plants, whereas leaves of LSW17S-treated plants did not exhibit typical disease progression. Minute brown spots were observed $18 \mathrm{~h}$ after inoculation. No further symptom of the disease was observed. Similar perturbation was observed on the leaves inoculated with avirulent DC3000(avrRpm1). In addition, BTH and LSW17S treatments protected Arabidopsis approximately 60 and 58\%, respectively (Fig. 1B). Pathogen proliferation also was inhibited significantly by LSW17S treatment. On the other hand, DH5 $\alpha$ did not affect disease progression.

\section{Defense-related gene expression}

by LSW17S and pathogen challenge.

To investigate the mechanisms of disease protection conferred by LSW17S, transcript accumulations of three pathogenesisrelated $(P R)$ genes and $P D F 1.2$ were examined. LSW17S treatment alone did not induce $P R 1$ and PDF1.2 mRNA accumulations in Arabidopsis (Fig. 2). However, expressions of all four defense-related genes were observed at 12 to $24 \mathrm{~h}$ postinoculation (hpi) in the compatible interaction. Transcript accumulation

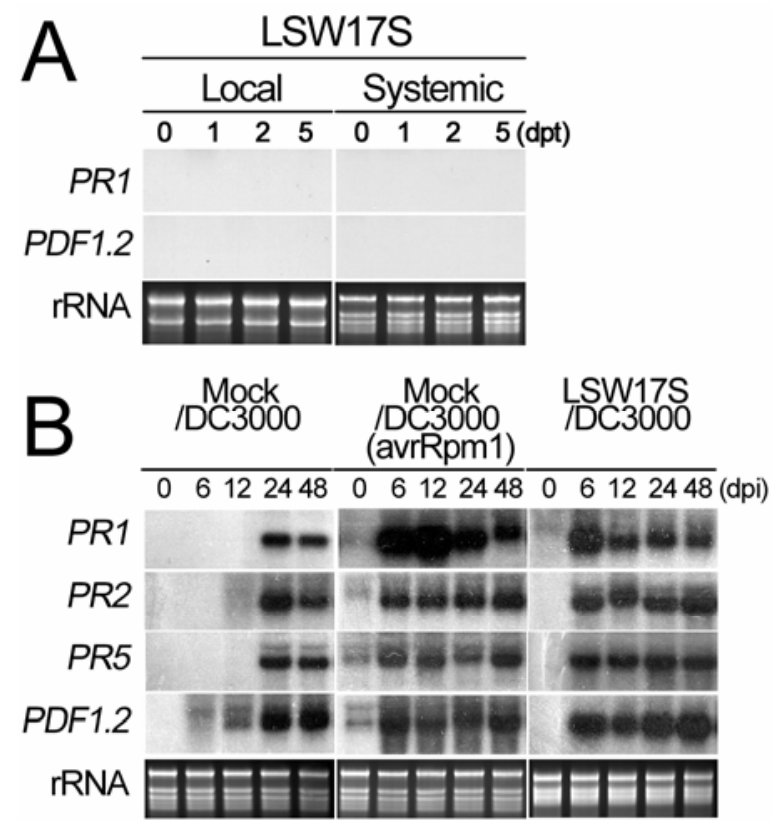

Fig. 2. Effect of LSW17S and pathogen challenge on the expression of $P R$ and PDF 1.2 genes. Arabidopsis plants $(n=25)$ were mock treated $(0.85 \%$ $\mathrm{NaCl}$ ) or treated with LSW17S in $0.85 \% \mathrm{NaCl}$ and challenged 5 days later with virulent DC3000 or avirulent DC3000(avrRpm1); dpi and dpt = days postinoculation and days posttreatment, respectively. A, Transcriptions of PR1 and PDF1.2 genes in Arabidopsis treated with LSW17S. RNAs from LSW17S-treated Arabidopsis roots (Local) and from leaves (Systemic) that were harvested at indicated time points. The blots were hybridized with Arabidopsis $P R 1$ and $P D F 1.2$ probes labeled with $\left[{ }^{32} \mathrm{P}\right]$-dCTP. Equal sample loading was confirmed by ethidium-bromide staining of the rRNA in the gel. B, Transcription of $P R$ genes and PDF1.2 gene in Arabidopsis treated with LSW17S and challenged with virulent pathogen. Arabidopsis was mock and LSW17S treated Arabidopsis and challenged with virulent (DC3000) or avirulent DC3000(avrRpm1) pathogens. RNA was isolated from Arabidopsis leaves harvested at the indicated time points after inoculation, separated by denaturing gel electrophoresis, and transferred to nylon membranes. The blots were hybridized with Arabidopsis PR1, PR2, PR5, and $P D F 1.2$ probes labeled with $\left[{ }^{32} \mathrm{P}\right]-\mathrm{dCTP}$. Equal sample loading was confirmed by ethidium-bromide staining of the rRNA in the gel. attained a maximum level at $24 \mathrm{hpi}$. In the incompatible interaction, faster and stronger transcriptions of these genes were observed within 6 hpi. Rapid and fortified transcriptions of the four genes tested were observed at 6 to 48 hpi in Arabidopsis treated with LSW17S and challenged with virulent DC3000. Mock treatment did not affect mRNA synthesis of defense-related genes significantly (data not shown).

\section{Persistence and dose dependency of LSW17S effects.}

We investigated the duration of disease resistance by LSW17S in Arabidopsis. Arabidopsis was inoculated with DC3000 at 3, 5, and 10 days after LSW17S treatment. LSW17S treatment inhibited disease progression caused by DC3000 by 60, 51, and 64\% in Arabidopsis at 3, 5, and 10 days after treatment, respectively (Fig. 3A). Small, dark-brown lesions were observed on the inoculated leaves at $18 \mathrm{hpi}$. Robust transcriptions of PR1 and PDF1.2 genes were observed at 6 hpi in all LSW17S-treated plants (Fig. 3B). In addition, LSW17S significantly reduced disease progression at $10^{6}$ and $10^{8} \mathrm{CFU} / \mathrm{g}$ final densities (Fig. 4A and B). Disease progression also was inhibited significantly by both treatments. The fresh weight of plants increased with the $10^{6} \mathrm{CFU} / \mathrm{g}$ LSW17S treatment, but the difference in fresh weight of LSW17S- and mock-treated plants was not significant.
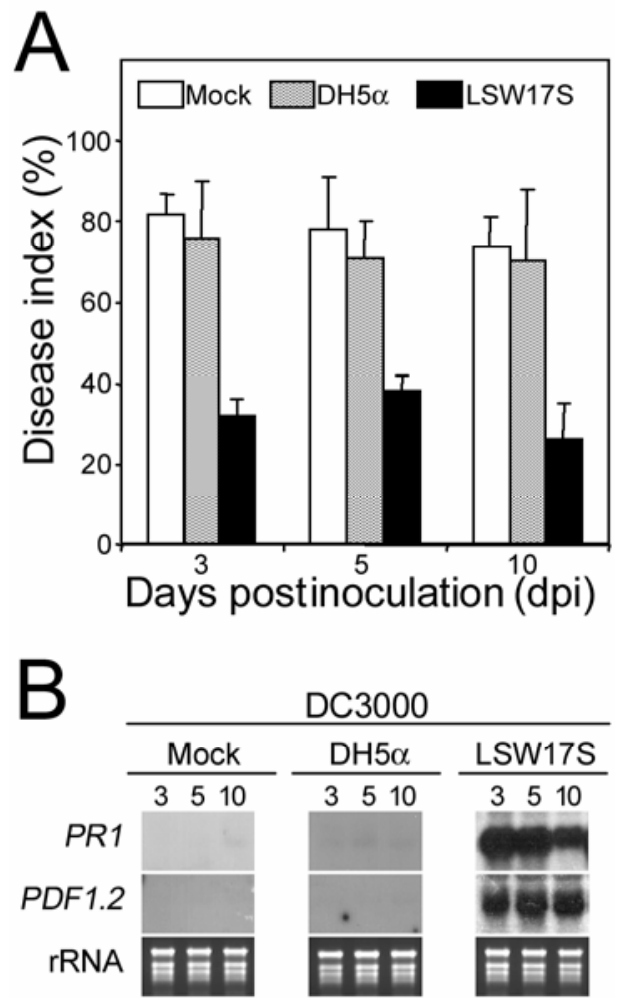

Fig. 3. Treatment of LSW17S suppresses bacterial infection of Arabidopsis up to 10 days through the induction of resistance responses. The Arabidopsis ecotype Col-0 was inoculated with Pseudomonas syringae pv. tomato DC3000 at 3, 5, and 10 days after LSW17S treatment. A, Bacterial disease progression in mock-, DH5 $\alpha$-, and LSW17S-treated Arabidopsis following DC3000 infection at 3, 5, and 10 days after each treatment. Each bar represents the mean of disease index with standard error from 20 to 25 plants. B, Transcriptions of PRI/PDF1.2 genes in Arabidopsis leaves inoculated with DC3000 at 3, 5, and 10 days after mock $(0.85 \% \mathrm{NaCl})$, Escherichia coli DH5 $\alpha$, or LSW17S treatments. Total RNA was extracted from the leaves of 25 plants $6 \mathrm{~h}$ postinoculation, separated by denaturing gel electrophoresis, and transferred to nylon membranes. The blots were hybridized with Arabidopsis $P R 1$ and $P D F 1.2$ probes labeled with $\left[{ }^{32} \mathrm{P}\right]-$ dCTP. Equal sample loading was confirmed by ethidium-bromide staining of the rRNA in the gel. 
Production of hydrogen peroxide and callose induction.

The effects of LSW17S and DC3000 challenge on hydrogen peroxide accumulation and callose induction at 6 and $24 \mathrm{hpi}$ were determined. Both responses provide reliable evidence of whether or not plants are primed. Hydrogen peroxide and callose production were absent in LSW17S- or mock-treated Arabidopsis (Fig. 5). In contrast, these defense-related responses were highly regulated within the leaf tissue or trichome of plants treated with LSW17S and recovered 6 and $24 \mathrm{~h}$ after DC3000 challenge. Inoculation was performed 5 days after LSW17S treatment. The level of defense responses was similar with Arabidopsis challenged with avirulent pathogen DC3000 (avrRpm1).

\section{Priming by LSW17S is dependent}

on ethylene, jasmonic acid, and NPRI gene.

To analyze the mode of action of LSW17S on the resistance of Arabidopsis against DC3000, the ecotype Col-0, one

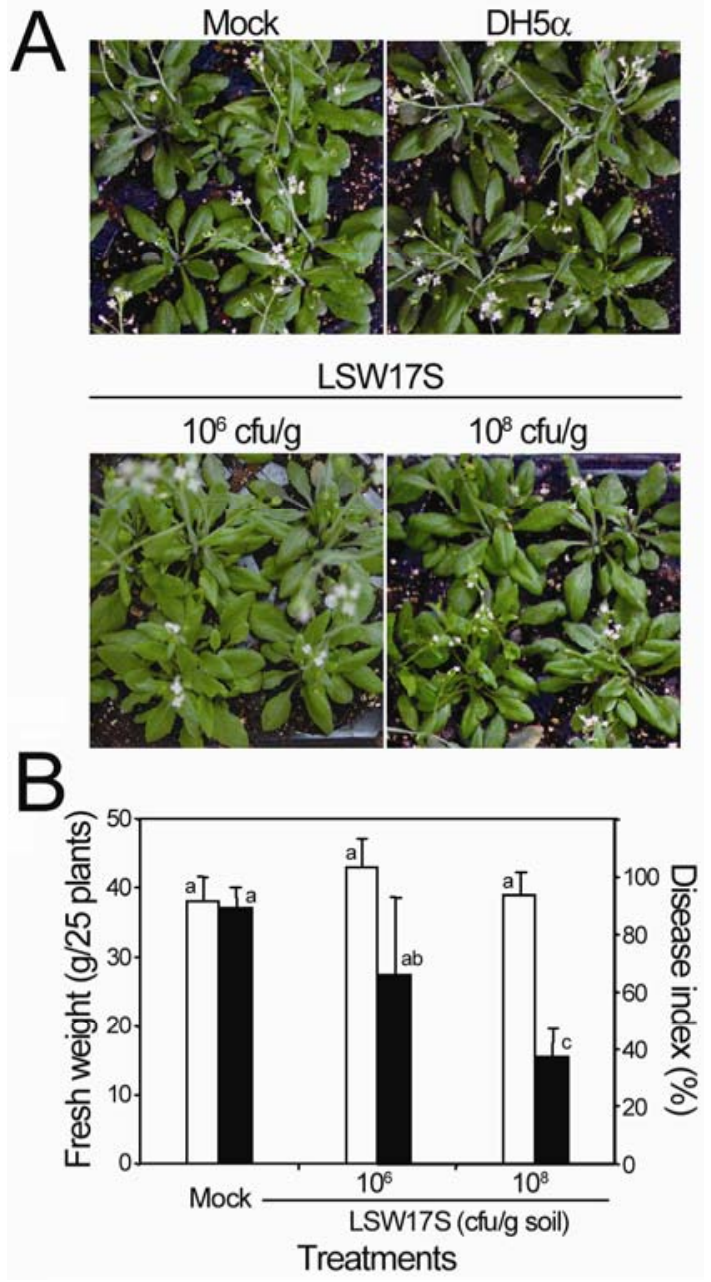

Fig. 4. Growth and pathogen proliferation in Arabidopsis Col-0 plants treated with increasing concentrations of LSW17S. Bacterization with LSW17S and Pseudomonas syringae pv. tomato DC3000 challenge were performed, except the $10^{6}$ concentration of LSW17S. A, Growth of Arabidopsis plants treated with increasing concentration of LSW17S. Arabidopsis did not show any distinctive alterations given the different concentrations of LSW17S. B, Quantification of plant growth and disease inhibition by increasing concentration of LSW17S 10 days after treatment. The disease index was evaluated as described in Figure 1. Each bar represents the mean of fresh weight and disease index with standard error from 25 plants. Different letters indicate statistically significant differences between treatments (Duncan's multiple range tests; $P<0.05$ ). All experiments were done more than three times and similar results were obtained. transgenic Col-0, and the three mutants were treated with LSW17S 5 days prior to pathogen inoculation. LSW17S treatment protected NahG (a line expressing bacterial NahG) plants from DC3000 invasion. However, it did not confer nprl (a mutant that does not accumulate PRI in response to salicylic acid), etrl (an altered perception of ethylene mutant), and jarl (a mutant that displays reduced sensitivity to methyl jasmonate) with disease resistance (Fig. 6A). Therefore, the disease-protecting effect induced by LSW17S is dependent on ethylene, jasmonic acid, and NPR1. LSW17S was recovered from the rhizosphere of all plant lines without significant differences (Fig. 6B); therefore, the loss of diseaseprotecting capacity in $n p r l$, etrl, and jarl is not due to poor colonization. In addition, streptomycin-resistant bacteria were absent from leaf extracts of all the plant lines. These results indicate that priming by LSW17S is translocated systemically (data not shown).

To investigate the mode of action of priming by LSW17S at the molecular and cellular levels, we examined the transcription of $P R 1 / P D F 1.2$ via reverse-transcription polymerase chain reaction (RT-PCR) and production of hydrogen peroxide or callose induction in the LSW17S-treated Col-0, transgenic Col-0 expressing NahG, and its mutants with or without the subsequent challenge of DC3000. LSW17S treatment did not affect the assessed molecular and cellular responses (Figs. 6C and D). Faster and fortified inductions of hydrogen peroxide at 6 hpi and callose at 24 hpi were evident in the Col-0 and NahG treated with LSW17S and challenged with DC3000. The npr1, etrl, and jarl mutations impaired the defense responses. Transcriptions of $P R 1$ and $P D F 1.2$ also were induced at 6 hpi in the Col-0 plants pretreated with LSW17S. Hence, LSW17S alone did not induce expression of both genes. PRI transcription was not observed in NahG; however, LSW17S and DC3000 induced PDF1.2 expression in the same plants at 6 hpi. Transcription of both genes was almost completely abolished by the nprl, etrl, and jarl mutations.

\section{DISCUSSION}

We previously found that tomato (L. esculentum L.) wilt disease, caused by Fusarium oxysporum f. sp. lycopersici, is significantly inhibited if soil is drenched with $P$. putida LSW17S (Lee 2004). Additional investigations revealed that the same treatment also protects eggplant, tomato, and red pepper from bacterial wilt, and that LSW17S inhibits conidial germination and mycelial growth of several plant-pathogenic fungi. To further examine the protection conferred by LSW17S and its underlying resistance mechanisms, the effects of LSW17S on the interaction between $A$. thaliana and a virulent bacterial pathogen, $P$. syringae pv. tomato DC3000, were investigated.

\section{P. putida LSW17S confers systemic resistance in Arabidopsis.}

Our results here clearly demonstrate that LSW17S protects Arabidopsis from infection by DC3000. Repeated challenge tests corroborated this disease-protecting capacity. Although previous study has shown that LSW17S inhibits the conidial germination of plant-pathogenic fungus and protects tomato against $F$. oxysporum infection, neither LSW17S nor its culture filtrate arrests DC3000 growth in vitro (data not shown). Control of multiple diseases in numerous host species in the absence of direct pathogen inhibition is a typical characteristic of systemic resistance induced by rhizobacteria (Jetiyanon et al. 2003; Kloepper et al. 2004; Krause et al. 2003; Raupach and Kloepper 1998; Zhang et al. 2004). Therefore, we concluded that LSW17S induces systemic resistance in Arabidopsis against DC3000 infection. 


\section{Priming by LSW17S.}

Following LSW17S treatment, when the plants were challenged with DC3000, mRNA synthesis of PRl genes and PDF1.2 gene was accelerated and potentiated (Fig. 2). However, neither LSW17S treatment nor DC3000 challenge alone induced the transcription activation. Although resistance-inducing agents protect disease progression and upregulate expression of defense-related genes, a relationship between them is not obligated. Similar to the present results, viral infection has been found to trigger augmented expression of defense-related genes in tobacco treated with rhizobacteria conferring systemic resistance (Ahn et al. 2002). Expression of the tobacco PR-1a gene has been triggered by endophytic bacterium (Park and Kloepper 2000). On the other hand, a P. fluorescens strain did

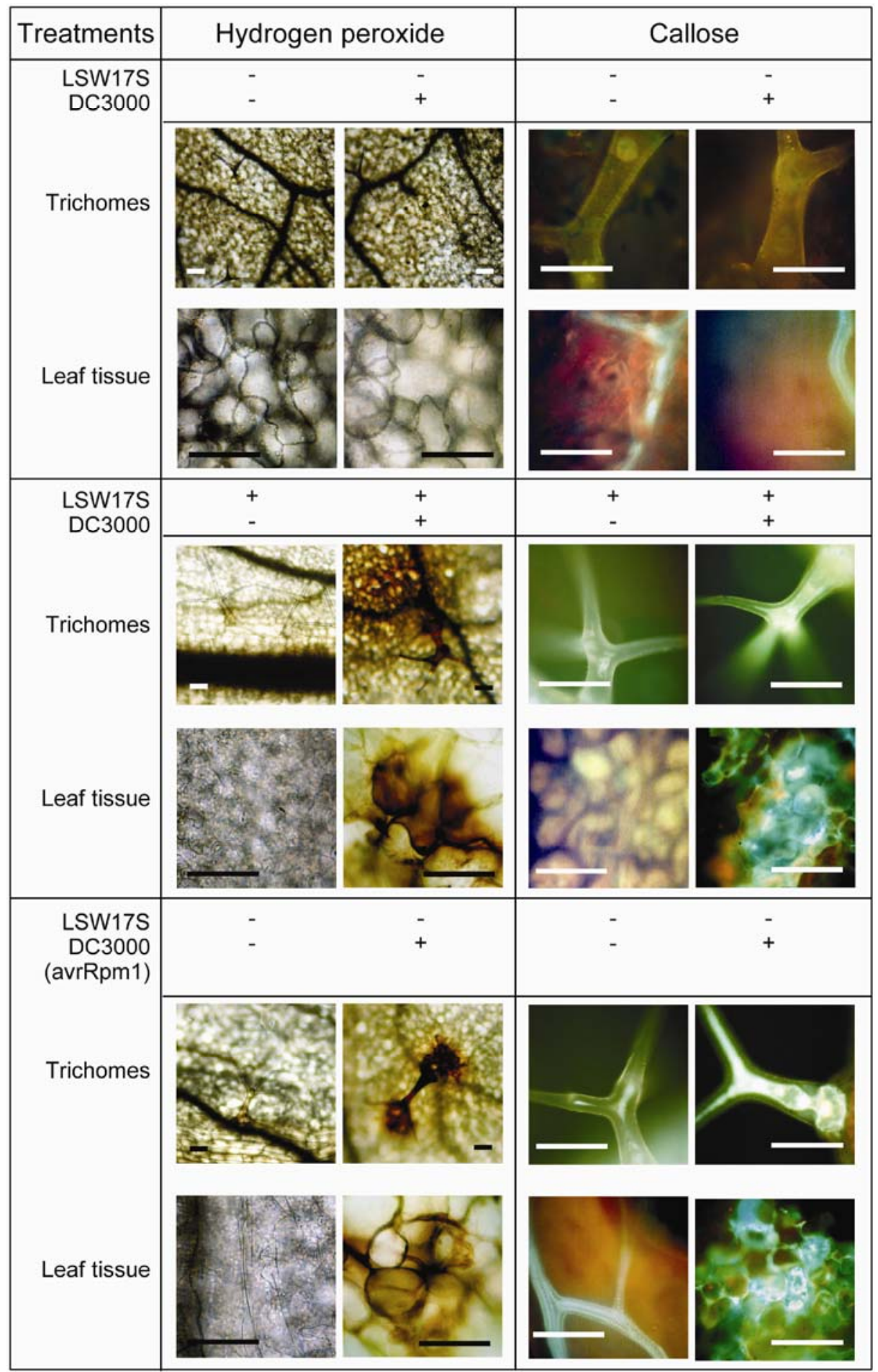

Fig. 5. Effect of priming by LSW17S on hydrogen peroxide accumulation and callose deposition in Arabidopsis. Four-week-old Arabidopsis plants were grown in horticultural soil mix supplemented with LSW17S (+) at $10^{8} \mathrm{CFU} / \mathrm{g}$ in $0.85 \% \mathrm{NaCl}$ or with $0.85 \% \mathrm{NaCl}$ only (-). Five days later, leaves of the plants were sprayed with Tween $20(-)$ at $250 \mu \mathrm{g} / \mathrm{ml}$, inoculated with virulent Pseudomonas syringae pv. tomato DC $3000\left(10^{8} \mathrm{CFU} / \mathrm{ml}\right)(\mathrm{DC} 3000 ;+)$ or with avirulent $P$. syringae pv. tomato DC3000 expressing avrRpm1 $\left(10^{8} \mathrm{CFU} / \mathrm{ml}\right)(\mathrm{DC} 3000[\mathrm{avrRpm} 1] ;+)$. Accumulation of hydrogen peroxide and callose deposition was seen under light and epifluorescence microscope as described in Materials and Methods. Bars $=50 \mu \mathrm{m}$. All experiments were done more than three times and similar results were obtained. 
not affect transcription of $P R$ genes and the $P D F 1.2$ gene in Arabidopsis in spite of its obvious disease protection capacity regardless of the pathogen infection (Pieterse et al. 1996; van Wees et al. 1999). These results and our data demonstrate that defense-related gene expressions are not reliable evidence in determining whether a plant is in a resistant or armed state, suggesting that the mode of action of systemic resistance by rhizobacteria is host or strain specific. Microarray analyses also confirmed these results (Cartieaux et al. 2003; Kloepper et al. 2004; Verhagen et al. 2004; Wang et al. 2005).

Priming by LSW17S persists for a long period. LSW17Sinduced disease resistance lasted up to 10 days (Fig. 3A). In addition, pathogen challenge triggered accelerated expression of PRI and PDF1.2 in Arabidopsis pretreated with LSW17S.
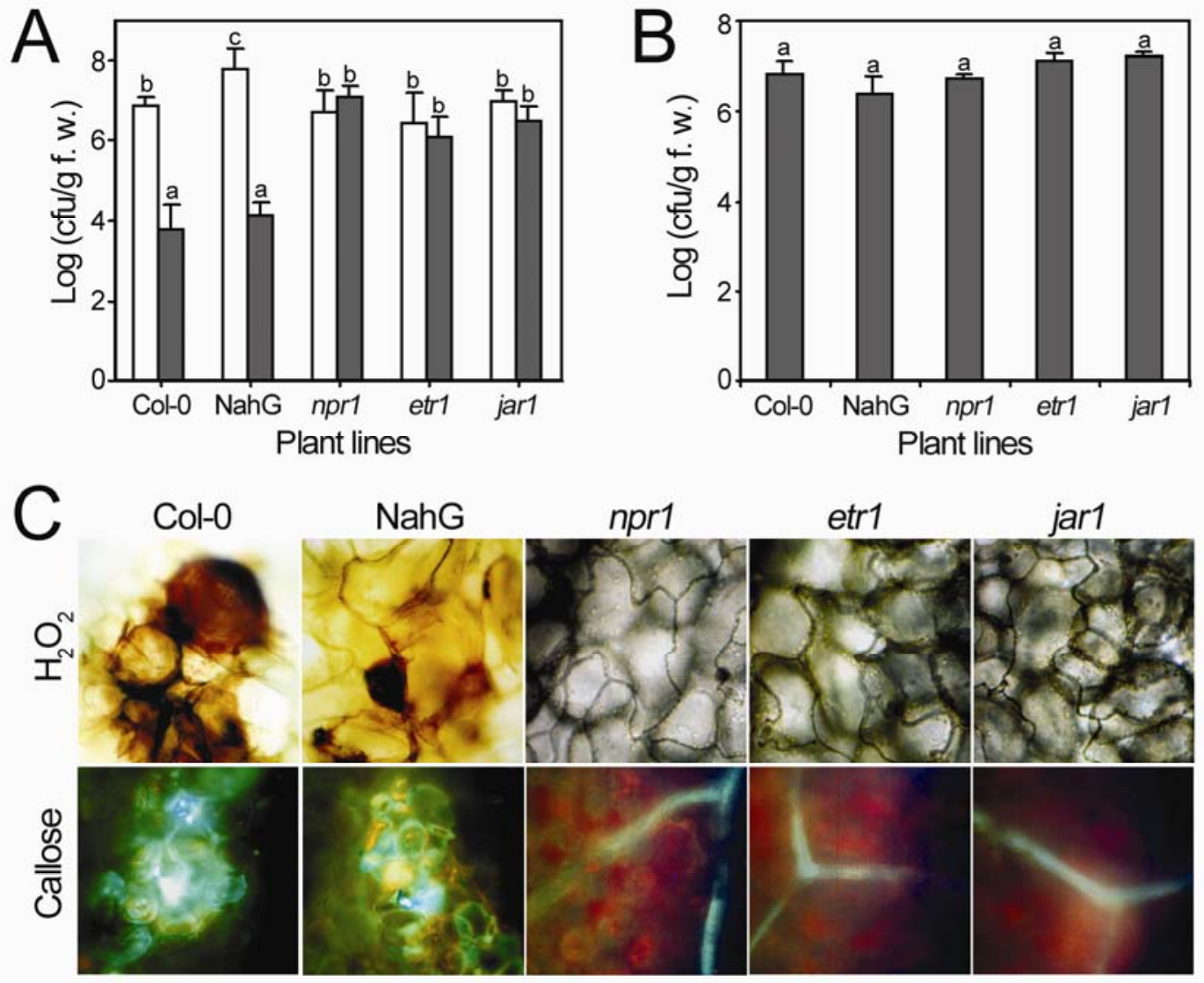

D

\begin{tabular}{|c|c|c|c|c|c|c|c|c|c|c|c|c|c|c|c|c|c|c|c|c|c|c|c|}
\hline & & & & & & & & & & & & & & & & & & & & & & & $1-0$ \\
\hline LSW17S & - & - & & + & - & - & & + & - & & & + & - & & + & + & 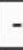 & & + & & + & \multirow[b]{2}{*}{ ๘ } & \multirow{2}{*}{$\frac{\overleftarrow{S}}{\Sigma}$} \\
\hline DC3000 & - & + & - & + & - & + & & + & 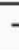 & & & + & - & & - & + & 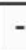 & $\mathrm{T}$ & - & & + & & \\
\hline
\end{tabular}

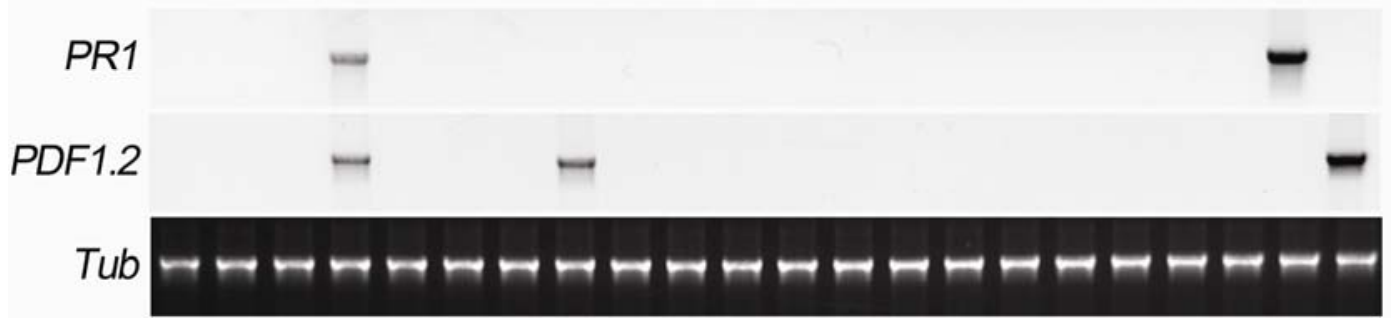

Fig. 6. Systemic resistance and cellular and molecular defense responses of LSW17S-treated Arabidopsis Col-0, NahG, npr1, etrl, and jarl against Pseudomonas syringae pv. tomato DC3000. A, Numbers of DC3000 in leaves of the Arabidopsis thaliana ecotype Col-0 and signaling mutants of the same ecotype treated with LSW17S 5 days prior to bacterial inoculation. Different letters indicate statistically significant differences between mock- and LSW17S-treated plants (Duncan's multiple range tests; $P<0.05$ ). Open bars, mock-treated Arabidopsis leaves; solid bars, LSW17S-treated Arabidopsis leaves. B, Colonization of Arabidopsis by LSW17S. Arabidopsis roots were harvested five days after LSW17S treatment and the number of colony-forming units of streptomycinresistant LSW17S was estimated as described in Materials and Methods. Data are means with standard errors from 20 to 25 plants. Different letters indicate statistically significant differences between treatments (Duncan's multiple range tests; $P<0.05$ ). C, Hydrogen peroxide accumulation and callose deposition in Arabidopsis. Treatment and observation were conducted. D, Analysis of PR1 and PDF1.2 gene expression by reverse-transcription polymerase chain reaction (RT-PCR) in Arabidopsis five days after LSW17S treatment and 6 hpi with DC3000. First-strand cDNA was synthesized using 50 ng of total RNA isolated from leaves of the indicated plant and treatment combinations and anchored oligo-dT. PCR product was obtained after amplification of $0.5 \mu$ of first-strand cDNA and each gene-specific primer. The products were analyzed by using gene-specific probes. 
Long-lasting priming indicates the successful colonization and successful interaction between host and LSW17S. In the previous research, we also found stable colonization by LSW17S on and within tomato roots (Lee et al. 2005). Persistence of rhizobacteria-induced systemic resistance against plant-pathogenic fungi, bacteria, and nematodes has been described in tomato (Yan et al. 2002), Arabidopsis (van Wees et al. 1997), and potato (Hallmann et al. 2001). LSW17S at $10^{6} \mathrm{CFU} / \mathrm{g}$ promoted Arabidopsis growth through several repeated experiments, but the increase in fresh weight was not significant. LSW17S treatment inhibited fungal and bacterial diseases of tomato and significantly increased growth of Solanaceous crops (Lee et al. 2005). Hence, growth-promoting activity in LSW17S is plant species specific. Taken together, LSW17S should be a good candidate for biological control of multiple potent diseases in Cruciferous and Solanaceous crops.

The effects of LSW17S on cellular defense responses were investigated to determine the relationship between priming and systemic resistance induced by LSW17S. No discrete hydrogen peroxide accumulation was detected in the LSW17S- or mock-treated leaves (Fig. 5). However, strong hydrogen peroxide accumulation was observed in the leaf tissues and trichomes treated with DC3000 5 days later. Similarly, higher peroxidase activity was observed in tomato and pigeon pea treated and inoculated with rhizobacteria and pathogens (Podile and Laxmi 1998; Silva et al. 2004). Formation of callose also was investigated because hydrogen peroxide is one of the secondary signaling messengers regulating defense responses. LSW17S treatment and subsequent pathogen challenge were required for callose deposition. Similarly, newly formed callose was accumulated within and around the infection sites in roots of pea treated with rhizobacteria (Benhamou et al. 1996, 1998). These results and our findings support the concept that primed Arabidopsis treated with LSW17S is in a surveillance state extremely sensitive to pathogen challenge. In addition, priming by LSW17S and $R$-gene-dependent resistance share several cellular and molecular defense mechanisms, including hydrogen peroxide accumulation, callose deposition, and expression patterns of defense-related genes.

\section{Priming by LSW17S is dependent \\ on ethylene, jasmonic acid, and NPRI.}

To investigate defense-signaling pathways regulated by LSW17S, disease-inhibiting activities, hydrogen peroxide accumulation, callose deposition, and PRI/PDF 1.2 transcriptions were assessed in the Arabidopsis signaling mutants that failed to respond to salicylic acid, ethylene, and jasmonic acid (Fig. 6).

The pathogen proliferation in planta clearly was reduced in LSW17S-treated Col-0 and bacterial NahG-transgenic plants; however, this inhibitory effect was not evident in nprl, etrl, and jarl plants in spite of the successful colonization of LSW17S (Fig. 6A and B). This is additional potent evidence that disease protection by LSW17S is based on plant-mediated ISR and not on antibiosis. In addition, rapid and accelerated expressions of both $P R I$ and $P D F 1.2$ were triggered by pathogen challenge in the Col-0 plants pretreated with LSW17S (Figs. 2B and 3B), and nprl, etrl, and jarl mutations impaired PRI/PDF1.2 transcriptions by priming (Fig. 6D). These results indicate that the concealed resistance state conferred by LSW17S extends its effects through ethylene, jasmonic acid, and NPRI. Induction of systemic resistance within NahGtransgenic plants and impairment of this resistance by nprl, etrl, and jarl have been described in Arabidopsis treated with a $P$. fluorescens WCS417r and another rhizobacterium (Pieterse et al. 1996; Ryu et al. 2003). Although defense signaling in our study is not novel, comparative analyses on defense mechanisms for systemic resistance between LSW17S and WCS417r re- vealed significantly different responses. Augmented expression of $P R$ genes was observed in Arabidopsis treated with LSW17S and then infected with DC3000, whereas WCS417r treatment did not induce $P R$ gene transcription regardless of the pathogen infection (van Wees et al. 1999; Verhagen et al. 2004). Our results also showed that, in LSW17S-primed Arabidopsis, pathogen challenge triggered higher hydrogen peroxide accumulation and callose deposition. However, WCS417r did not trigger transcription of Arabidopsis genes related to production of AOS within leaves regardless of the subsequent pathogen challenge. Although this result does not absolutely exclude the possibility that reactive oxygen species could play a role in WCS417r-mediated ISR, there has been no report about the effects of WCS417r on the production of AOS within Arabidopsis.

In summary, LSW17S primes and induces cellular and molecular defense mechanisms in Arabidopsis against pathogens. Bacterization with LSW17S primes the plant into a highly competent state for a long time in the absence of detectable physiological variations. Priming has physiological and genetic importance, and it is one of the most economical and effective modes of resistance because it prevents dispensable metabolic consumption in plants. Plants divert this metabolic investment for growth and other fitness-related processes (Bostock 2005; Heil 2001; Purrington 2000). Recently, costs and benefits of priming were analyzed and compared with those of systemic acquired resistance by BTH or constitutive activation of resistance by $c p r l$ mutation (van Hulten et al. 2006). Plant growth and seed production in primed Arabidopsis are superior even when disease occurs. Along with conventional antibiotics, previously developed plant defense activators, biocontrol organisms, and improved seed varieties, LSW17S could be a novel disease control strategy that is environmentally friendly.

\section{MATERIALS AND METHODS}

\section{Plants and pathogen challenge.}

Seed of $A$. thaliana ecotype Col-0, Col-0 expressing bacterial the NahG gene, and its signaling mutants nprl, etrl, and jarl were obtained from The Arabidopsis Information Resource. Arabidopsis plants were grown in a growth chamber at $22^{\circ} \mathrm{C}$, 65 to $70 \%$ relative humidity, and $16 \mathrm{~h}$ of illumination daily. Four-week-old A. thaliana plants were used for bacterial and chemical treatments.

The DC3000 strain of $P$. syringae pv. tomato containing pVSP61 (DC3000) and pVSP61 carrying avrRpm1 (DC 3000 [avrRpm1]) were cultivated on King's medium B (Difco Laboratories, Detroit) containing kanamycin at $50 \mu \mathrm{g} / \mathrm{ml}$ for 2 days at $28^{\circ} \mathrm{C}$ (Bisgrove et al. 1994; Grant et al. 1995). To inoculate Arabidopsis, bacterial cells were retrieved from the medium with $0.85 \% \mathrm{NaCl}$ solution supplemented with Tween 20 at 250 $\mu \mathrm{g} / \mathrm{ml}$, and the concentration was adjusted to $1 \times 10^{8} \mathrm{CFU} / \mathrm{ml}$. In all, 25 Arabidopsis plants were inoculated 5 days after transplantation into LSW17S-supplemented horticultural soil mix. Plants were inoculated by spraying bacterial suspension until all the leaves were covered with fine droplets. The inoculated plants were kept in a dew chamber for $16 \mathrm{~h}$ at $25^{\circ} \mathrm{C}$ and $100 \%$ relative humidity, then transferred to a growth chamber. Disease severity was estimated as described previously (Pieterse et al. 1996) with some modifications. Five days after inoculation, disease severity was assessed by determining the percentage of leaves per plant with typical yellowing or water-soaking symptoms (25 plants per treatment). Moreover, CFU within $1 \mathrm{~g}$ (fresh weight) of Arabidopsis leaves from each of five plants per treatment through plating dilutions on King's B medium containing kanamycin at $50 \mu \mathrm{g} / \mathrm{ml}$ was estimated. 
Treatment of microorganisms and chemicals.

P. putida LSW17S and E. coli DH5 $\alpha$ kept at $-70^{\circ} \mathrm{C}$ as $15 \%$ glycerol stock were grown on tryptic soy agar (TSA; Difco Laboratories) at $28^{\circ} \mathrm{C}$ for $48 \mathrm{~h}$. For bacterial treatment of Arabidopsis plants, cell suspensions of LSW17S and DH5 $\alpha$ were retrieved from the colonies on TSA with sterilized $0.85 \%$ $\mathrm{NaCl}$ solution and the concentration of cell suspension was adjusted with the same solution. Arabidopsis plants were transplanted into cylindrical plastic pots $(10 \mathrm{~cm}$ in diameter by $8 \mathrm{~cm}$ in height) containing horticultural soil amended with bacterial suspension 5 days prior to pathogen challenge, unless otherwise indicated. To minimize physical damage by transplanting, Arabidopsis and soil were transferred into the pots at the same time. DH5 $\alpha$ and increasing concentrations of LSW17S were applied to Arabidopsis. The whole plants were recovered and their fresh weights were measured 10 days after treatment. Pots with growing Arabidopsis were dipped into 1.2 $\mathrm{mM}$ solutions of BTH (Sigma-Aldrich, St. Louis) for $30 \mathrm{~min} 5$ days prior to pathogen challenge. There were five replicates for each treatment on a total of 25 plants per treatment.

Detection of LSW17S within rhizosphere and plant leaves.

Roots ( $\pm 1 \mathrm{~g}$ fresh weight) were recovered 5 days after LSW17S treatment and spun in $9 \mathrm{ml}$ of sterilized $0.85 \% \mathrm{NaCl}$ solution at $400 \times g$. Leaves $( \pm 1 \mathrm{~g}$ fresh weight $)$ were harvested at the same time and ground with $9 \mathrm{ml}$ of $0.85 \% \mathrm{NaCl}$ containing $0.5 \mathrm{~g}$ of glass beads. Each dilution was plated on TSA supplemented with streptomycin at $150 \mu \mathrm{g} / \mathrm{ml}$ to estimate streptomycin-resistant LSW17S. After $36 \mathrm{~h}$ of incubation at $28^{\circ} \mathrm{C}$, the number of streptomycin-resistant $\mathrm{CFU}$ per gram of root and leaf fresh weight was determined.

\section{Histochemistry: hydrogen peroxide and callose.}

The effects of LSW17S and pathogen challenge on priming and, thereby, plant responses such as oxidative burst and callose deposition were determined. LSW17S-treated leaves were sprayed or infiltrated with virulent DC3000 5 days after LSW17S treatment. Histochemical detection of superoxide and hydrogen peroxide were performed as described previously (Wohlgemuth et al. 2002), with minor modification. To visualize accumulation of hydrogen peroxide, leaves were stained with $0.1 \%$ (wt/vol) diaminobenzidine (DAB). Then, the leaves were cleared with $96 \%$ ( $\mathrm{vol} / \mathrm{vol})$ ethanol and preserved in $50 \%$ ( $\mathrm{vol} / \mathrm{vol}$ ) ethanol. DAB staining indicates hydrogen peroxide as red-brown precipitate under the light microscope. To determine callose deposition, recovered leaves were fixed with lactophenol (95\% alcohol/phenol $=2: 1$, vol $/ \mathrm{vol})$ and stained with $0.1 \%$ (wt/vol) aniline blue as described (Reuber et al. 1998); fluorescence of callose was detected with an epifluorescence microscope (E800; Nikon, Tokyo) using a V-2A filter. All experiments were performed at least three times with similar results.

\section{RNA isolation and expression analyses.}

Total RNA was extracted from Arabidopsis plants by lithium chloride precipitation (Davis and Ausubel 1989). For hybridization analysis, $10 \mu \mathrm{g}$ of total RNA was separated electrophoretically in denaturing formaldehyde-agarose gels (8\% formaldehyde, $0.5 \times$ morpholinepropanesulfonic acid, $1.5 \%$ agarose) and blotted onto Hybond-N+ membrane (Amersham Pharmacia Biotech, Buckinghamshire, U.K.) by capillary transfer. RNA gel blots were hybridized, washed, and exposed to X-ray film (Fuji Photo Film, Kanagawa, Japan). DNA probes were labeled with $\left[{ }^{32} \mathrm{P}\right]$-dCTP by random primer labeling (Boehringer $\mathrm{GmbH}$, Mannheim, Germany). Analyses of $P R 1$ and $P D F 1.2$ gene expressions were performed using the RT-PCR as described (Pieterse et al. 1998) with some modifications. First-strand
cDNA was synthesized from $50 \mathrm{ng}$ of total RNA of the leaves recovered 5 days after bacterization at $6 \mathrm{hpi}$, using the Reverse-iT first-strand synthesis kit and anchored oligo-dT as indicated by the manufacturer's instructions (ABGene, Epsom, U.K.). Independent PCR using equal aliquots $(0.5 \mu \mathrm{l})$ of cDNA samples was performed using PR1/PDF1.2-specific primers described (Vieira Dos Santos et al. 2003). Each PCR product was blotted and Southern analyses were performed using PRI or $P D F 1.2$ probe labeled with $\left.{ }^{[32} \mathrm{P}\right]$-dCTP. The tubulin gene $(T U B)$ was amplified as a quantitative control (Lee et al. 2000).

\section{ACKNOWLEDGMENTS}

This research was supported by grants from the National Institute of Agricultural Biology to I.-P. Ahn and a grant to S.-C. Suh from the Crop Functional Genomics Center of the 21st Century Frontier Research Program (CG2211) funded by the Ministry of Science and Technology and the Rural Development Administration of the Korean government. We deeply thank M. E. M. Orden for editing this article.

\section{LITERATURE CITED}

Ahn, I.-P., Park, K., and Kim, C. H. 2002. Rhizobacteria-induced resistance perturbs viral disease progress and triggers defense-related gene expression. Mol. Cells 13:302-308.

Alvarez, M. E., Pennell, R. I., Meijer, P., Ishikawa, A., Dixon, R. A., and Lamb, C. J. 1998. Reactive oxygen intermediates mediate a systemic signal network in the establishment of plant immunity. Cell 92:773-784.

Benhamou, N., Kloepper, J. W., Quadt-Hallman, A., and Tuzun, S. 1996. Induction of defense-related ultrastructural modifications in pea root tissues inoculated with endophytic bacteria. Plant Physiol. 112:919-929.

Benhamou, N., Kloepper, J. W., and Tuzun, S. 1998. Induction of resistance against Fusarium wilt of tomato by combination of chitosan with an endophytic bacterial strain: ultrastructure and cytochemistry of the host response. Planta 204:153-168.

Bennett, M., Mehta, M., and Grant, M. 2005. Biophoton imaging: A nondestructive method for assaying $R$ gene responses. Mol. Plant-Microbe Interact. 18:95-102.

Bisgrove, S. R., Simonich, M. T., Smith, N. M., Sattler, A., and Innes, R. W. 1994. A disease resistance gene in Arabidopsis with specificity for two different pathogen avirulence genes. Plant Cell 6:927-933.

Bolwell, G. P., Butt, V. S., Davies, D. R., and Zimmerlin, A. 1995. The origin of the oxidative burst in plants. Free Radical Res. 23:517-532.

Bolwell, G. P., Davies, D. R., Gerrish, C., Auh, C.-K., and Murphy, T. M. 1998. Comparative biochemistry of the oxidative burst produced by rose and French bean cells reveals two distinct mechanisms. Plant Physiol. 116:1379-1385.

Bostock, R. M. 2005. Signal crosstalk and induced resistance: straddling the line between cost and benefit. Annu. Rev. Phytopathol. 43:545-580.

Buysens, S., Heungens, K., Poppe, J., and Hofte, M. 1996. Involvement of pyochelin and pyoverdin in suppression of Pythium-induced dampingoff of tomato by Pseudomonas aeruginosa 7NSK2. Appl. Environ. Microbiol. 62:865-871.

Cartieaux, F., Thibaud, M.-C., Zimmerli, L., Lessard, P., Sarrobert, C., David, P., Gerbaud, A., Robaglia, C., Somerville, S., and Nussaume, L. 2003. Transcriptome analysis of Arabidopsis colonized by a plantgrowth promoting rhizobacterium reveals a general effect on disease resistance. Plant J. 36:177-188.

Chamnongpol, S., Willekens, H., Moeder, W., Langebartels, C., Sandermann, H., Jr., Van Montagu, M., Inze, D., and Van Camp, W. 1998. Defense activation and enhanced pathogen tolerance induced by $\mathrm{H}_{2} \mathrm{O}_{2}$ in transgenic tobacco. Proc. Natl. Acad. Sci. U.S.A. 95:5818-5823.

Chen, C., Belanger, R. R., Benhamou, N., and Paulitz, T. C. 2000. Defense enzymes induced in cucumber roots by treatment with plant growthpromoting rhizobacteria (PGPR) and Pythium aphanidermatum. Physiol. Mol. Plant Pathol. 56:13-23.

Cho, H. J., Hayashi, T., Datta, S. K., Takabayashi, K., Van Uden, J. H., Horner, A., Corr, M., and Raz, E. 2002. IFN- $\beta$. promote priming of antigen-specific CD8+ and CD4+ T lymphocytes by immunostimulatory DNA-based vaccines. J. Immunol. 168:4907-4913.

Conrath, U., Thulke, O., Katz, V., Schwindling, S., and Kohler, A. 2001. Priming as a mechanism in induced systemic resistance of plants. Eur. J. Plant Pathol. 107:113-119.

Conrath, U., Pieterse, C. M. J., and Mauch-Mani, B. 2002. Priming in plant-pathogen interactions. Trends Plant Sci. 7:210-216. 
Davis, K. R., and Ausubel, F. M. 1989. Characterization of elicitor-induced defense responses in suspension-cultured cells of Arabidopsis. Mol. Plant-Microbe Interact. 2:363-368.

De Meyer, G., Capieau, K., Audenaert, K., Buchala, A., Metraux, J.-P., and Hofte, M. 1999. Nanogram amounts of salicylic acid produced by the rhizobacterium Pseudomonas aeruginosa 7NSK2 activate the systemic acquired resistance pathway in bean. Mol. Plant-Microbe Interact. 12:450-458.

Devadas, S. K., Enyedi, A., and Raina, R. 2002. The Arabidopsis hrl1 mutation reveals novel overlapping roles for salicylic acid, jasmonic acid and ethylene signaling in cell death and defense against pathogens. Plant J. 30:467-480.

Faize, M., Faize, L., Koike, N., Ishizaka, M., and Ishii, H. 2004. Acibenzolar-S-methyl-induced resistance to Japanese pear scab is associated with potentiation of multiple defense responses. Phytopathology 94:604-612.

Flors, V., Ton, J., Jakab, G., and Mauch-Mani, B. 2005. Abscisic acid and callose: team players in defence against pathogens? J. Phytopathol. 153:377-383

Friedrich, L., Lawton, K., Ruess, W., Masner, P., Specker, N., Rella, M. G., Meier, B., Dincher, S. S., Staub, T., Uknes, S., Metraux, J.-P., Kessmann, H., and Ryals, J. A. 1996. A benzothiadiazole derivative induces systemic acquired resistance in tobacco. Plant J. 10:61-70.

Gaffney, T., Friedrich, L., Vernooij, B., Nagrotto, D., Nye, G., Uknes, S., Ward, E., Kessmann, H., and Ryals, J. 1993. Requirement of salicylic acid for the induction of systemic acquired resistance. Science 261:754 756

Gorlach, J., Volrath, S., Knauf-Beiter, G., Hengy, G., Beckhove, U., Kogel, K. H., Oostendorp, M., Staub, T., Ward, E., Kessmann, H., and Ryals, J. 1996. Benzothiadiazole, a novel class of inducers of systemic acquired resistance, activates gene expression and disease resistance in wheat. Plant Cell 8:629-643.

Graham, M. Y., and Graham, T. L. 1994. Wound-associated competency factors are required for the proximal cell responses of soybean to the Phytophthora sojae wall glucan elicitor. Plant Physiol. 105:571-578.

Grant, M. R., Godiard, L., Straube, E., Ashfield, T., Lewald, J., Sattler, A., Innes, R. W., and Dangl, J. L. 1995. Structure of the Arabidopsis RPMI gene enabling dual specificity disease resistance. Science 269:843-846.

Hallmann, J., Quadt-Hallmann, A., Miller, W. G., Sikora, R. A., and Lindow, S. E. 2001. Endophytic colonization of plants by the biocontrol agent Rhizobium etli G12 in relation to Meloidogyne incognita infection. Phytopathology 91:415-422.

Heil, M. 2001. The ecological concept of costs of induced systemic resistance (ISR). Eur. J. Plant Pathol. 107:137-146.

Jakab, G., Cottier, V., Toquin, V., Rigoli, G., Zimmerli, L., Metraux, J.-P., and Mauch-Mani, B. 2001. $\beta$-Aminobutyric acid-induced resistance in plants. Eur. J. Plant Pathol. 107:29-37.

Jakab, G., Ton, J., Flors, V., Zimmerli, L., Metraux, J.-P., and MauchMani, B. 2005. Enhancing Arabidopsis salt and drought stress tolerance by chemical priming for its abscisic acid responses. Plant Physiol. 139:267-274.

Jetiyanon, K., Fowler, W. D., and Kloepper, J. W. 2003. Broad-spectrum protection against several pathogens by PGPR mixtures under field conditions in Thailand. Plant Dis. 87:1390-1394.

Jeun, Y. C., Park, K. S., Kim, C. H., Fowler, W. D., and Kloepper, J. W. 2004. Cytological observations of cucumber plants during induced resistance elicited by rhizobacteria. Biol. Control 29:34-42.

Kauss, H., Fauth, M., Merten, A., and Jeblick, W. 1999. Cucumber hypocotyls respond to cutin monomers via both an inducible and a constitutive $\mathrm{H}_{2} \mathrm{O}_{2}$-generating system. Plant Physiol. 120:1175-1182.

Kim, S. T., Kim, S. G., Hwang, d. H., Kang, S. Y., Kim, H. J., Lee, B. H., Lee, J. J., and Kang, K. Y. 2004. Proteomic analysis of pathogen-responsive proteins from rice leaves induced by rice blast fungus, $\mathrm{Mag}$ naporthe grisea. Proteomics 4:3569-3578.

Kloepper, J. W., Ryu, C.-M., and Zhang, S. 2004. The nature and application of biocontrol microbes: Bacillus spp.-induced systemic resistance and promotion of plant growth by Bacillus spp. Phytopathology 94:1259-1266.

Krause, M. S., De Ceuster, T. J. J., Tiquia, S. M., Michel, F. C., Jr., Madden, L. V., and Hoitink, H. A. J. 2003. Isolation and characterization of rhizobacteria from composts that suppress the severity of bacterial leaf spot of radish. Phytopathology 93:1292-1300.

Lee, H., Suh, S.-S., Park, E., Cho, E., Ahn, J. H., Kim, S.-G., Lee, J. S., Kwon, Y. M., and Lee, I. 2000. The AGAMOUS-LIKE 20 MADS domain protein integrates floral inductive pathways in Arabidopsis. Genes Dev. 14:2366-2376

Lee, S.-W. 2004. Biological control of tomato disease by Pseudomonas species. Ph.D. thesis, Seoul National University, Seoul, Korea.

Lee, S.-W., Ahn, I.-P., Lim, J.-W., and Lee, Y.-H. 2005. Pseudomonas putida strain 17 isolated from replant soil promotes plant growth and inhibits conidial germination of soilborne plant pathogens. Plant Pathol. J. 21:244-251.

Lu, G., Jantasuriyarat, C., Zhou, B., and Wang, G. L. 2004. Isolation and characterization of novel defense response genes involved in compatible and incompatible interactions between rice and Magnaporthe grisea. Theor. Appl. Genet. 108:525-534.

Ludewig, B., Ehl, S., Karrer, U., Odermatt, B., Hengartner, H., and Zinkernagel, R. M. 1998. Dendritic cells efficiently induce protective antiviral immunity. J. Virol. 72:3812-3818.

McDowell, J. M., and Dangl, J. L. 2000. Signal transduction in the plant immune response. Trends. Biochem. Sci. 25:79-82.

Olivain, C., Trouvelot, S., Binet, M.-N., Cordier, C., Pugin, A., and Alabouvette, C. 2003. Colonization of flax roots and early physiological responses of flax cells inoculated with pathogenic and nonpathogenic strains of Fusarium oxysporum. Appl. Environ. Microbiol. 69:5453-5462

Ongena, M., Daayf, F., Jacques, P., Thonart, P., Benhamou, N., Paulitz, T. C., and Belanger, R. R. 2000. Systemic induction of phytoalexins in cucumber in response to treatments with fluorescent pseudomonads. Plant Pathol. 49:523-530.

Pare, P. W., Farag, M. A., Krishnamachari, V., Zhang, H., Ryu, C.-M., and Kloepper, J. W. 2005. Elicitors and priming agents initiate plant defense responses. Photosynthesis Res. 85:149-159.

Park, D.-S., Landini, S., Graham, M. Y., and Graham, T. L. 2002. Induced distal defence potentiation against Phytophthora sojae in soybean. Physiol. Mol. Plant Pathol. 60:293-310.

Park, K. S., and Kloepper, J. W. 2000. Activation of $P R-1 a$ promoter by rhizobacteria that induce systemic resistance in tobacco against Pseudomonas syringae pv. tabaci. Biol. Control 18:2-9.

Park, K., Park, H.-J., Jeun, Y.-C., Kim, C.-H., and Kloepper, J. W. 2000. Induced systemic resistance against anthracnose in cucumber plant by a selected PGPR, Bacillus amyloliquefaciens and its mechanism of action. In: Fifth International PGPR Workshop, Cordoba, Argentina.

Pieterse, C. M., van Wees, S. C., Hoffland, E., van Pelt, J. A., and van Loon, L. C. 1996. Systemic resistance in Arabidopsis induced by biocontrol bacteria is independent of salicylic acid accumulation and pathogenesis-related gene expression. Plant Cell 8:1225-1237.

Pieterse, C. M. J., van Wees, S. C. M., van Pelt, J. A., Knoester, M., Laan, R., Gerrits, H., Weisbeek, P. J., and van Loon, L. C. 1998. A novel signaling pathway controlling induced systemic resistance in Arabidopsis. Plant Cell 10:1571-1580.

Pieterse, C., M. J., van Pelt, J. A., Ton, J., Parchmann, S., Mueller, M. J. Buchala, A. J., Metraux, J.-P., and van Loon, L. C. 2000. Rhizobacteriamediated induced systemic resistance (ISR) in Arabidopsis requires sensitivity to jasmonate and ethylene but is not accompanied by an increase in their production. Physiol. Mol. Plant Pathol. 57:123-134

Pieterse, C. M. J., van Pelt, J. A., van Wees, S. C. M., Ton, J., LeonKloosterziel, K. M., Keurentjes, J. J. B., Verhagen, B. W. M., Knoester, M., van der Sluis, I., Bakker, P. A. H. M., and van Loon, L. C. 2001 Rhizobacteria-mediated induced systemic resistance: triggering, signalling and expression. Eur. J. Plant Pathol. 107:51-61.

Podile, A. R., and Laxmi, V. D. V. 1998. Seed bacterization with Bacillus subtilis AF 1 increases phenylalanine ammonia-lyase and reduces the incidence of fusarial wilt in pigeonpea. J. Phytopathol. 146:255-259.

Pozo, M. J., Van Loon, L. C., and Pieterse, C. M. J. 2004. Jasmonatessignals in plant-microbe interactions. J. Plant Growth Regul. 23:211-222.

Purrington, C. B. 2000. Costs of resistance. Curr. Opin. Plant Biol. 3:305308.

Ramamoorthy, V., Viswanathan, R., Raguchander, T., Prakasam, V., and Samiyappan, R. 2001. Induction of systemic resistance by plant growth promoting rhizobacteria in crop plants against pests and diseases. Crop Prot. 20:1-11.

Raupach, G. S., and Kloepper, J. W. 1998. Mixtures of plant growth-promoting rhizobacteria enhance biological control of multiple cucumber pathogens. Phytopathology 88:1158-1164.

Reuber, T. L., Plotnikova, J. M., Dewdney, J., Rogers, E. E., Wood, W., and Ausubel, F. M. 1998. Correlation of defense gene induction defects with powdery mildew susceptibility in Arabidopsis enhanced disease susceptibility mutants. Plant J. 16:473-485

Ryu, C.-M., Kim, Y.-C., Anderson, A. J., and Kloepper, J. W. 2000. Induction of defense responses related to active oxygen species by PGPR. In: Fifth International PGPR Workshop, Cordoba, Argentina

Ryu, C.-M., Hu, C.-H., Reddy, M. S., and Kloepper, J. W. 2003. Different signaling pathways of induced resistance by rhizobacteria in Arabidopsis thaliana against two pathovars of Pseudomonas syringae. New Phytol. 160:413-420

Si-Ammour, A., Mauch-Mani, B., and Mauch, F. 2003. Quantification of induced resistance against Phytophthora species expressing GFP as a vital marker: $\beta$-aminobutyric acid but not BTH protects potato and Arabidopsis from infection. Mol. Plant Pathol. 4:237-248. 
Silva, H. S. A., Romeiro, R. d. S., Macagnan, D., Halfeld-Vieira, B. D. A Pereira, M. C. B., and Mounteerd, A. 2004. Rhizobacterial induction of systemic resistance in tomato plants: non-specific protection and increase in enzyme activities. Biol. Control 29:288-295.

Tenhaken, R., Levine, A., Brisson, L. F., Dixon, R. A., and Lamb, C. J. 1995. Function of the oxidative burst in hypersensitive disease resistance. Proc. Natl. Acad. Sci. U.S.A. 92:4158-4163.

Ton, J., and Mauch-Mani, B. 2004. $\beta$-Aminobutyric acid-induced resistance against necrotrophic pathogens is based on ABA-dependent priming for callose. Plant J. 38:119-130.

Ton, J., Davison, S., van Loon, L. C., and Pieterse, C. M. J. 2001. Heritability of rhizobacteria-mediated induced systemic resistance and basal resistance in Arabidopsis. Eur. J. Plant Pathol. 107:63-68.

Ton, J., Jakab, G., Toquin, V., Flors, V., Iavicoli, A., Maeder, M. N., Metraux, J.-P., and Mauch-Mani, B. 2005. Dissecting the $\beta$-aminobutyric acid-induced priming phenomenon in Arabidopsis. Plant Cell 17:987-999.

Umemura, K., Ogawa, N., Shimura, M., Koga, J., Usami, H., and Kono, T. 2003. Possible role of phytocassane, rice phytoalexin, in disease resistance of rice against the blast fungus Magnaporthe grisea. Biosci. Biotechnol. Biochem. 67:899-902.

van Hulten, M., Pelser, M., van Loon, L. C., Pieterse, C. M. J., and Ton, J. 2006. Costs and benefits of priming for defense in Arabidopsis. Proc. Natl. Acad. Sci. U.S.A. 103:5602-5607.

van Wees, S. C. M., Pieterse, C. M. J., Trijssenaar, A., van 't Westende, Y A. M., Hartog, F., and van Loon, L. C. 1997. Differential induction of systemic resistance in Arabidopsis by biocontrol bacteria. Mol. PlantMicrobe Interact. 10:716-724.

van Wees, S. C., Luijendijk, M., Smoorenburg, I., van Loon, L. C., and Pieterse, C. M. 1999. Rhizobacteria-mediated induced systemic resistance (ISR) in Arabidopsis is not associated with a direct effect on expression of known defense-related genes but stimulates the expression of the jasmonate-inducible gene Atvsp upon challenge. Plant Mol. Biol. 41:537-549.

van Wees, S. C. M., DeSwart, E. A. M., van Pelt, J. A., van Loon, L. C., and Pieterse, C. M. J. 2000. Enhancement of induced disease resistance by simultaneous activation of salicylate- and jasmonate-dependent defense pathways in Arabidopsis thaliana. Proc. Natl. Acad. Sci. U.S.A. 97:8711-8716.

Verhagen, B. W. M., Glazebrook, J., Zhu, T., Chang, H.-S., van Loon, L. C., and Pieterse, C. M. J. 2004. The transcriptome of rhizobacteria-induced systemic resistance in Arabidopsis. Mol. Plant-Microbe Interact. 17:895-908.

Vieira Dos Santos, C., Letousey, P., Delavault, P., and Thalouarn, P. 2003. Defense gene expression analysis of Arabidopsis thaliana parasitized by Orobanche ramosa. Phytopathology 93:451-457.

Wang, Y., Ohara, Y., Nakayashiki, H., Tosa, Y., and Mayama, S. 2005. Microarray analysis of the gene expression profile induced by the endophytic plant growth-promoting rhizobacteria, Pseudomonas fluorescens FPT9601-T5 in Arabidopsis. Mol. Plant-Microbe Interact. 18:385-396.

Wohlgemuth, H., Mittelstrass, K., Kschieschan, S., Bender, J., Weigel, H.-J., Overmyer, K., Kangasjarvi, J., Sandermann, H., and Langebartels, C. 2002. Activation of an oxidative burst is a general feature of sensitive plants exposed to the air pollutant ozone. Plant Cell Environ. 25:717-726.

Wojtaszek, P. 1997. Oxidative burst: an early plant response to pathogen infection. Biochem. J. 322:681-692.

Yan, Z., Reddy, M. S., Ryu, C.-M., McInroy, J. A., Wilson, M., and Kloepper, J. W. 2002. Induced systemic protection against tomato late blight elicited by plant growth-promoting rhizobacteria. Phytopathology 92:1329-1333.

Yang, Y., Shah, J., and Klessig, D. F. 1997. Signal perception and transduction in plant defense responses. Genes Dev. 11:1621-1639.

Yedidia, I., Benhamou, N., and Chet, I. 1999. Induction of defense responses in cucumber plants (Cucumis sativus L.) by the biocontrol agent Trichoderma harzianum. Appl. Environ. Microbiol. 65:1061-1070.

Zhang, S., Reddy, M. S., and Kloepper, J. W. 2004. Tobacco growth enhancement and blue mold disease protection by rhizobacteria: Relationship between plant growth promotion and systemic disease protection by PGPR strain 90-166. Plant Soil 262:277-288.

Zimmerli, L., Jakab, G., Metraux, J. P., and Mauch-Mani, B. 2000. Potentiation of pathogen-specific defense mechanisms in Arabidopsis by $\beta$ aminobutyric acid. Proc. Natl. Acad. Sci. U.S.A. 97:12920-12925. 